\title{
Sosialisasi Pengurangan Penggunaan Sedotan Plastik Di Lingkungan Sekolah dan Masyarakat
}

\section{Dissemination of Reduction in Use of Plastic Straws in Schools and Communities}

\author{
Syahda Agustian S, Mahrifa Dwi Safitri dan Aina Fauzia
}

Jurusan Pendidikan Biologi, FMIPA, UNY,

Email: Syahdaagustian.2017@student.uny.ac.id

\begin{abstract}
Abstrak
Sedotan plastik terkandung didalamnya Polypropylene dan Polystyrene adalah salah satu alat bantu minum yang penggunaannya hanya digunakan sesaat dan akhirnya menambah jumlah limbah yang ada. Limbah sedotan plastik yang ada di lingkungan Kota Yogyakarta merupakan salah satu elemen penyebab kerusakan lingkungan yang tidak mudah terurai karena berbahan plastik dan anorganik. Langkah untuk mencapai lingkungan yang bersih dari limbah plastik terutama limbah sedotan adalah dengan mengurangi penggunaannya dengan tidak memakai atau menggunakan sedotan ramah lingkungan dan mengolah limbahnya menjadi sebuah karya atau barang yang berguna atau bernilai harganya. Dari langkah yang akan dilakukan, perlu diwujudkan karya-karya dengan bahan utama limbah sedotan plastik dan pengedukasian serta pemanfaatan limbah sedotan plastik, yang menjadi konsentrasi pada penelitian ini bertujuan dapat; alternatif langkah mengurangi kerusakan lingkungan dan mencintai lingkungan alam, sumbangsih ide kepada siswa dan masyarakat, alternatif produk fungsional bagi siswa ataupun masyarakat, pelestarian lingkungan, dan meningkatkan nilai ekonomi limbah. Metodologi yang digunakan adalah observasi, sosialisasi dan studi literatur. Hasil obseravsi menunjukan bahwa penggunaan sedotan plastik masih banyak dilingkungan sekolah dan masyarakat namun ternyata banyak siswa dan masyrakat yang sadar untu segera mengganti sedotan plastik menjadi sedotan ramah lingkungan dan tergerak hatinya untuk mengolah limbah sedotan plastik menjadi barang yang memiliki manfaat lebih.
\end{abstract}

Kata kunci: sosialisasi, sedotan, plastik

\section{Abstract}

Plastic straws contained in it are Polypropylene and Polystyrene is one of the drinking aids which use is only used for a moment and finally adds to the amount of waste that is available. Waste plastic straws in the city of Yogyakarta is one of the elements that cause environmental damage that is not easily broken down because it is made of plastic and inorganic. The step to achieve a clean environment from plastic waste, especially waste straws, is to reduce its use by not using or using environmentally friendly straws and processing its waste into a work or item that is useful or worth the price. From the steps that will be taken, the works need to be realized with the main ingredients of plastic straw waste and the extraction and utilization of plastic straw waste, which becomes the focus of this research aims to be able to; alternative steps to reduce environmental damage and love the natural environment, contribute ideas to students and society, alternative functional products for students or society, environmental preservation, and increase the economic value of waste. The methodology used is observation, socialization and literature study. The results of observations show that the use of plastic straws is still a lot in the school and community environment, but it turns out that many students and communities are aware to immediately 
replace plastic straws into environmentally friendly straws and their heart is moved to process plastic straws into goods with more benefits.

Key words: socialization, straws, plastic 


\section{PENDAHULUAN}

Dewasa ini jumlah limbah padat semakin lama meningkat secara signifikan salah satunya di Kota Yogyakarta dengan jumlah 203,73 ton/ hari (Balai Lingkungan Hidup, 2013), hal itu disebabkan karena wilayah di sekitar Kota Yogyakarta merupakan salah satu daerah dengan jumlah konsentrasi populasi manusia yang cukup besardengan laju pertumbuhan 1,18 pada tahun 2010-2016 (BPS, Statistic Indonesia, 2017) mempengaruhi tingkat kebutuhan primer, sehingga secara tidak langsung hal tersebut dapat menciptakan aktivitas jual beli makanan dan minuman. Keadaan ini berpengaruh terhadap produksi limbah hasil konsumsi masyarakat sekitar Kota Yogyakarta, adapun jenis limbah terbanyak adalah limbah plastik. Menurut data Dinas Lingkungan Hidup Kota Yogyakarta, ada sejumlah 13.656,41 ton sampah plastik pada tahun 2016. Salah satu limbah plastik tersebut yaitu limbah sedotan plastik yang berasal dari warung warung tempat menjual minuman mulai dari kaki lima sampai cafecafe yang berpusat di wilayah Kota Yogyakarta.

Berdasarkan senyawanya, limbah dapat dikelompokan menjadi 2 yaitu organik dan anorganik. Limbah organik secara kimiawi merupakan segala limbah yang mengandung unsur karbon (C), sehingga meliputi limbah dari mahluk hidup (misalnya kotoran hewan dan manusia, sisa makanan, dan sisa-sisa tumbuhan mati), kertas, plastik, dan karet. Namun, secara umum sebagian besar orang mendefinisikan limbah organik sebagai limbah yang hanya berasal dari mahluk hidup (alami) dan sifatnya mudah busuk. Limbah anorganik didefinisikan sebagai segala limbah yang tidak dapat atau sulit terurai/busuk secara alami oleh mikroorganisme pengurai. Dalam hal ini, bahan organik seperti plastik, kertas, dan karet juga dikelompokkan sebagai limbah anorganik. Bahan-bahan tersebut sulit diurai oleh mikroorganisme sebab unsure karbonnya membentuk rantai kimia yang kompleks dan panjang (polimer). Sesuai dengan observasi lapangan yang dilakukan untuk memperoleh data dasar, timbunan sampah masyarakat Kota Yogyakarta saat ini diproyeksikan sebesar 203,73 ton/hari dengan jumlah penduduk pada tahun 2013 sebanyak 407.464 dan sampah yang terangkut ke Tempat Pemrosesan Akhir sampah (TPA) sebesar kurang lebih $1300 \mathrm{~m}^{3} /$ hari (Balai Lingkungan Hidup, 2013).

Limbah akan terus diproduksi dan tidak akan pernah berhenti selama manusia tetap ada. Bisa dibayangkan bahwa jumlah sampah atau limbah yang dihasilkan oleh penghuni bumi ini akan semakin meningkat. Sampah atau limbah sendiri merupakan salah satu bentuk konsekuensi dari adanya aktivitas manusia dan volumenya berbanding lurus dengan jumlah penduduk. Apabila tidak ditangani secara efektif dan efisien, eksistensi sampah di alam tentu akan berbalik menghancurkan kehidupan sekitarnya. Alam memang mempunyai andil besar dalam pengolahan sampah secara otomatis, terutama pada sampah organik. Akan tetapi, kerja keras alam dalam mengurai sampah secara natural sangat tidak berimbang dibanding berjuta ton volume sampah yang diproduksi setiap harinya (Putra \& Yuriandala, 2010)

Plastik sudah menjadi bagian kehidupan sehari-hari manusia. Dalam dua dasarwarsa terakhir, kemasan plastik telah merebut perhatian pasar kemasan dunia, menggantikan kemasan-kemasan sebelumnya seperti, kaleng dan gelas (Nasution, 2015)

Limbah atau sampah plastik di lingkungan masyarakat banyak yang berasal dari bahan polypropilena (PP). Plastik PP banyak di manfaatkan sebagai kantong plastik. Namun dibalik kelebihan bahan 
yang berbahan plastik terdapat masalah setelah barang tersebut tidak di gunakan. Bahan plastik tidak dapat membusuk, dan tidak dapat diuraikan oleh tanah sehingga dapat menimbulkan masalah baru. Daur ulang limbah plastik merupakan jalan satusatunya untuk mengurangi jumlah limbah plastik (Nugroho, Rahmad, \& Suhartoyo, 2018).

Kesadaran lingkungan terhadap sampah plastik dan pemanfaatannya belum maksimal oleh karena keterbatasan pengetahuan dan juga belum adanya perencanaan sistem pengolahan limbah plastik (Martana et al., 2018).

Selama ini, langkah yang paling sering dilakukan untuk menguraikan limbah plastik ialah dengan cara dibakar. Plastik sendiri memiliki senyawa zat dioksin yang berasal dari klorin. Pada umumnya peneliti menyebut dengan plastik polivinil klorid (PVC). Namun PVC pada plastik sulit diurai karena menyatu dengan zat lainnya.

Selain dengan cara membakar sampah plastik saat ini sudah banyak alternatif pengelolahan limbah plastik yang dilakukan, demi menekan pertambahan jumlah limbah sedotan plastik yang sering digunakan oleh masyarakat setiap harinya, dengan berbagai cara mulai dari memanfaatkan kembali limbah sedotan plastik sebagai produk yang memiliki nilai jual seperti produk kerajinan tangan. Kerajian di sini memliki arti bahwa kerajinan adalah hal yang berkaitan dengan buatan tangan atau kegiatan dengan barang yang dihasilkan melalui keterampilan tangan (kerajinan tangan). Kerajinan yang dibuat biasanya terbuat dari berbagai bahan dan kerajinan ini dapat menghasilkan hiasan atau benda hias maupun barang pakai atau barang yang memiliki manfaat (Ridho, 2016). Pemanfaatan limbah sedotan plastik menjadi produk yang memiliki nilai jual merupakan upaya kreatif untuk memanfaatkan kembali limbah guna pelestarian lingkungan serta meningkatkan nilai ekonomi limbah yang tidak digunakan lagi.

Teknik yang digunakan dalam proses daur ulang sedotan plastik memiliki keterbatasan sehingga masih sangat kurang bervariatif, sehingga produk yang dihasilkan pun tidak menjangkau selera segmentasi yang dituju. Maksud kurang bervariatif disini, pengolahan sedotan plastik biasanya hanya dikumpulkan kemudian ada yang dibuat kerajinan tangan seperti bunga, atau hanya dikumpulkan saja. Selain limbah sedotan plastik yang perlu dimanfaatkan, pengedukasian masyarakat tentang pengurangan penggunaan sedotan plastik dirasa perlu digencarkan karena bila fokus pada sampahnya dan tidak berusaha menguranginya sama saja tidak ada pergerakan kemajuan didalamnya. Oleh sebab itu edukasi kepada masyarakat untuk mengganti sedotan palstik menjadi sedotan ramah lingkungan menjadi wajib hukumnya agar permasalahan lingkungan ini cepat teratasi.

Berdasarkan latar belakang kuantitas limbah sedotan plastik di Kota Yogyakarta belum termanfaatkan dan juga kesadaran masyarakat akan pentingnya mengurangi penggunaan sedotan plastik, maka penulis melihat bahwa edukasi tidak menggunakan sedotan plastik atau menggantinya dengan ramah lingkungan terhadap masyarakat dirasa perlu dilakukan dan adanya potesi untuk mengembangkan produk limbah sedotan plastik menjadi alternatif barang yang bermanfaat bagi siswa disekolah. Salah satu cara dalam mengolah limbah sedotan dapat diperoleh dengan teknik hot textile dengan menggunakan setrika. Desain yang dihasilkan memperoleh sifat sedotan yang pada awalnya lentur dan fleksibel, berubah menjadi keras dan kokoh. Atas dasar inilah penulis melihat sosialisasi tentang pengurangan penggunaan sedotan plastik perlu dilakukan dimasyarakat dan pemanfaatannya menjadi barang berguna 
dapat dilakukan untuk mengurangi limbah dan membuat limbah tersebut bermanfaat.

Limbah adalah sisa dari suatu usaha atau kegiatan. Limbah berbahaya dan beracun adalah sisa suatu usaha atau kegiatan yang mengandung bahan berbahaya dan beracun yang karena sifat, konsentrasi, dan atau jumlahnya, baik secara langsung maupun tidak langsung, dapat mencemarkan, merusak lingkungan hidup, atau membahayakan lingkungan hidup manusia serta makhluk hidup (Suharto, 2010).

Pengertian lain menyatakan bahwa limbah merupakan suatu zat atau benda buangan yang dihasilkan dari suatu proses produksi, baik industri maupun domestic (rumah tangga), yang kehadirannya pada saat tertentu tidak dikehendaki lingkungan karena menurunkan kualitas lingkungan dan juga dapat merusak lingkungan tersebut (Nabila, 2017).

Plastik merupakan salah satu bahan yang dapat dengan mudah kita temui disetiap jenis barang, seperti halnya botol minum, alat makanan (sendok, garpu, wadah, gelas), kantong pembungkus/kresek, $\mathrm{TV}$, kulkas, pipa pralon, plastik laminating, gigi palsu, sikat gigi, compact disk (CD), kutex (cat kuku), mainan anak-anak, mesin, alat-alat militer hingga pestisida. Berdasarkan penelitian, penggunaan plastik yang tidak memenuhi syarat dapat menimbulkan berbagai gangguan kesehatan, ini dikarenakan plastik dapat menjadi pemicu kanker dan kerusakan jaringan pada tubuh manusia atau yang biasanya kita sebut dengan karsinogenik. Selain itu, plastik pada umumnya sulit untuk didegradasikan atau diuraikan oleh organisme-organisme mikro seperti bakteri dan jamur. Berbagai penelitian telah menghubungkan BisphenolA dosis rendah menyebabkan beberapa dampak terhadap kesehatan, seperti meningkatkan kadar prostat, menurunkan kandungan hormon testoteron, memungkinkan terjadinya kanker payudara, sel prostat menjadi lebih sensitif terhadap hormon dan kanker, dan membuat seseorang menjadi hiperaktif (Karuniastuti, 2017).

Plastik merupakan bahan yang terbentuk dari produk polimerisasi sintetik atau semi-sintetik yang mempunyai sifatsifat unik dan luar biasa. Polimer sendiri adalah adalah rantai berulang dari atom yang panjang, terbentuk dari pengikat yang berupa molekul identik yang disebut monomer. Jika monomernya sejenis disebut homopolimer, dan jika monomernya berbeda akan menghasilkan kopolimer. Proses polimerisasi yang menghasilkan polimer berantai lurus mempunyai tingkat polimerisasi yang rendah dan kerangka dasar yang mengikat antar atom karbon dan ikatan antar rantai lebih besar daripada rantai hidrogen. Bahan yang dihasilkan dengan tingkat polimerisasi rendah bersifat kaku dan keras (Flinn and Trojan, 1975).

Sekitar 150 tahun yang lalu, plastik dibuat dengan menggunakan material yang memiliki harga murah namun dengan formulasi yang ringan akan tetapi memiliki sifat yang kuat (Annisa, 2019).

Limbah plastik adalah salah satu masalah terbesar, karena limbah plastik termasuk sebagai material yang tidak mudah untuk diurai oleh alam, baik oleh air hujan dan panas matahari atau panas api maupun oleh mikroba tanah. Plastik merupakan satu produk kimia yang sudah dikenal dan digunakan secara luas oleh seluruh lapisan masyarakat, baik masyarakat yang bermukim di pedesaan maupun di perkotaan. Dampak negatif dari limbah plastik selain mengganggu pemandangan yang merusak lingkungan, karena plastik yang dihancurkan dengan cara dibakar, abunya tidak dapat dicerna oleh tanah juga mengakibatkan gas beracun yang berbahaya bagi makhluk hidup (Sabatari, 2007).

Sedotan adalah sebuah tabung yang dimaksudkan untuk mentransfer minuman 
dari wadah ke mulut peminum, dengan penerapan kekuatan mengisap. Sedotan yang paling awal berbentuk cekungan batang rumput dan benar-benar terbuat dari rumput / jerami. Sebuah tabung plastik tipis (seperti polypropylene dan polystyrene) atau bahan lain, lurus atau dengan engsel seperti akordeon, itu digunakan oleh salah satu ujung di mulut dan lain di akhir minum. Tindakan itu mengurangi tekanan udara di mulut, lalu kekuatan tekanan atmosfer minuman sampai jerami.

Karakteristik sedotan plastik:

- Lentur/fleksibel

- Ringan

- Tembus cahaya

- Mudah dibentuk

- Dapat meleleh jika terkena api

- Tahan air

- Tahan benturan

\section{Solusi/Teknologi}

Pendidikan lingkungan menjadi tanggung jawab segenap masyarakat, namun pengajar biologi dan pemerhati lingkungan hidup menjadi garda terdepan dalam penyelanggaraan pembelajaran ini. Siswa sekolah menjadi sasaran yang tepat dalam pembelajaran ini karena harapannya adalah siswa inilah yang nantinya akan menyebarluaskan hasil pembelajaran lingkungan hidup kepada masyarakat dilingkungannya masing-masing (Handziko, 2017).

Solusi yang ditawarkan dari permasalahan limbah sedotan plastik ini adalah dilakukannya sosialisasi guna mengurangi penggunaan sedotan plastik terhadap siswa Sekolah Dasar (SD) dan juga masyarakat umum. Selain melakukan sosialisasi ditawarkan pula kepada seluruh elemen masyarakat yang terlibat untuk menggunakan sedotan ramah lingkungan seperti stainless steel, sedotan kaca dan sedotan bambu. Selain penawaran sedotan ramah lingkungan. Terdapat pelatihan pembuatan karya menggunakan limbah sedotan plastik terhadap siswa Sekolah Dasar (SD). Pemanfaatan limbah plastik dalam hal ini dapat digunakan sebagai alternatif media belajar, seperti halnya pembuatan karya. Pemanfaatan limbah plastik sebagai media belajar antara lain pemanfaatan limbah plastik sedotan/pipet (Hodriana, 2013). Pengambilan solusi sosialisasi dikarenakan dengan adanya edukasi dapat membentuk pribadi yang cinta lingkungan dan dapat menyebarkan sifat tersebut pada orang lain. Saran dalam menggunakan sedotan ramah lingkungan adalah solusi utama untuk mengurangi sampah sedotan plastik. Dengan penggunaan sedotan ramah lingkungan, diharapkan dapat mengurangi jumlah sampah sedotan plastik yang ada di dunia.

Selama kegiatan berlangsung yang menjadi tantangan dalam menyelesaikan kegiatan ini adalah pada saat melakukan sosialisasi. Dimana setiap orang memiliki tanggapan yang berbeda dengan cara penyampaian yang berbeda pula. Pada anak $\mathrm{SD}$, mereka akan lebih senang ketika kegiatan sosialisasi dilakukan dengan cara menyenangkan dengan diselipkan berbagai macam game atau kegiatan yang mampu mengasah kemampuan kinetis mereka. Mereka akan lebih antusias ketika kegiatan lebih interaktif.

Pada saat sosialisasi di Taman Rekreasi Alun-Alun Selatan Yogyakarta, cara yang digunakan adalah metode wawancara dan memberi solusi. Dikarenakan tujuan pada kegiatan di tempat ini adalah untuk melakukan sosialisasi terhadap pedagang dan pengunjung, sehingga menggunakan pendekatan sosial. Beberapa pedagang dan pengunjung memberikan respon positif dengan cara mau menjawab wawancara dengan antusias, namun beberapa ada yang menolak untuk diwawancari. 


\section{Hasil dan Diskusi}

Berdasarkan Sosialisasi yang telah dilakukan, untuk sosialisasi pertama dilakukan di SD Muhammadiyah Blunyah. Dipilihnya SD Muhammadiyah Blunyah dikarenakan berdasarkan survey, SD tersebut salah satu tempat dengan pengguna sedotan plastik yang banyak di Yogyakarta. Ini ditilik dari wawancara dengan penjual di warung sekitar SD Muhammadiyah Blunyah. Dalam waktu dua hari, warung yang berjualan didaerah sekolah tersebut dapat menghabiskan 30-80 batang sedotan plastik sekali pakai. Setelah sedotan-sedotan tersebut digunakan, sedotan sekali pakai tersebut langsung dibuang ketempat sampah dan langsung menuju ke tempat akhir pembuangan sampah tanpa diolah terlebih dahulu. Kemudian dilakukan sosialisasi terhadap siswa-siswi di SD tersebut. Dan hasilnya, banyak siswa yang mulai jajan minuman dengan membawa sedotan ramah lingkungan tidak sekali pakai (sedotan bambu). Diarahkan juga kepada penjual warung untuk menerapkan sistem minta sedotan baru diberi sedotan bukan langsung diberi sedotan tanpa diminta.

Peran dari berbagai pihak merupakan salah satu kunci keberhasilan suatu kegiatan ataupun program termasuk program pengurangan penggunaan sedotan plastik ini. Peran generasi milenial, sebagai sosok yang muda, yang dinamis, yang penuh energi, dan optimis, diharapkan dapat menjadi agen perubahan. Generasi milenial, diharapkan mampu membawa ide-ide segar, pemikiran-pemikiran kreatif dengan metode thinking out of the box yang inovatif. Dengan kata lain generasi milenial diharapkan mampu menjadi pemimpin masa depan yang lebih baik dari pemimpin masa kini. Generasi milenial diharapkan untuk menjadi change agent, yaitu pihak yang mendorong terjadinya transformasi dunia ini ke arah yang lebih baik melalui efektifitas, perbaikan dan pengembangan untuk kehidupan di masa yang akan datang terutama perbaikan masalah lingkungan oleh sebab itu edukasi mengenai pengurangan penggunaan sedotan plastik dilakukan di jenjang persekolahan (Dewi, 2018).

Pada kegiatan sosialisasi yang telah kami lakukan terdapat beberapa kendala saat melakukannya. Seperti saan sosialisasi di SD Muhammadiyah Blunyah, terdapat beberapa kendala dengan cara berkomunikasi dengan anak SD tersebut. Tentunya harus dengan pendekatan yang berbeda sehingga mereka dapat memahami materi sosialisasi yang disampaikan. Anakanak biasanya juga akan lebih aktif bergerak dan berbicara ngelnatur. Mereka akan mengucapkan kata-kata yang masih lugu. Keaktifan mereka menjadi salah satu titik penting dalam kegiatan ini. Partisipasi mereka dalam bertanya dan menjawab sangat mempengaruhi jalannya kegiatan sosialisasi ini.

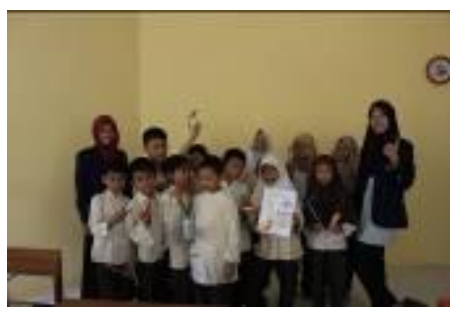

Gambar 1. kegiatan sosialisasi Di SD Muhammadiyah Blunyah

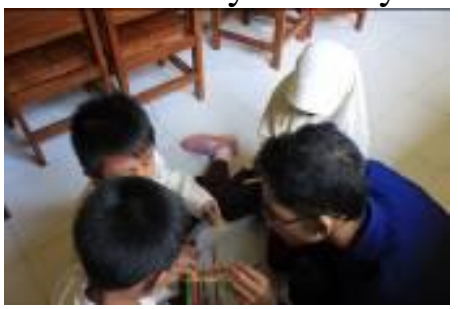

Gambar 2. Kegiatan Pelatihan pengolahan limbah sedotan palstik 


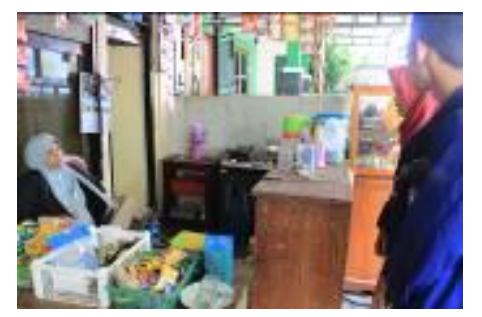

Gambar 3. Kegiatan sosialiasi di warung sekolah

Kegiatan sosialisasi yang kedua dilakukan di pusat rekreasi Alun-alun Selatan Kota Yogyakarta. Pemilihan Alunalun Selatan Kota Yogyakarta sebagai tempat sosialisasi adalah banyaknya pedagang yang ada pada area tersebut dengan ditambah pengunjung yang selalu datang pada siang maupun malam hari. Pedagang yang ada sebagian besar merupakan pedagang minuman yang pastinya akan menggunakan sedotan. Sehingga perlu adanya edukasi untuk mengurangi penggunaan limbah sedotan plastik di area Alun-alun Selatan Kota Yogyakarta. Berdasarkan hasil observasi, di area tersebut terdapat 43 warung penjual minuman dengan menggunakan sedotan yang dalam sehari dapat menghabiskan 50100 batang sedotan tiap warungnya. Kemudian kegiatan sosialisasi dilakukan dengan mengedukasi pengunjung diarea tersebut untuk menggunakan sedotan ramah lingkungan (sedotan bambu) dan juga mensosialisasikan kepada penjual minuman diarea Alun-Alun Selatan untuk tidak memberikan sedotan plastik langsung kepada konsumen kecuali konsumen tersebut memintanya. Dan hasilnya, beberapa warung telah menerapkan aturan tersebut dan banyak konsumen yang memilih untuk meminum langsung dari gelas tanpa menggunakan sedotan sehingga penggunaan sedotan palstik dapat terkurangi.

Beberapa kendala saat sosialisasi yang kedua yakni di Tempat Rekreasi AlunAlun Selatan Yogyakarta, kami masih menemukan beberapa kendala, yaitu banyak pedagang yang masih acuh terhadap kegiatan sosialisasi ini. Beberapa bahkan menolak untuk diwawancarai sehingga kami hanya menawarkan solusi kepada beberapa pedagang yang mau menerima kegiatan sosialisasi ini saat diwawancarai.

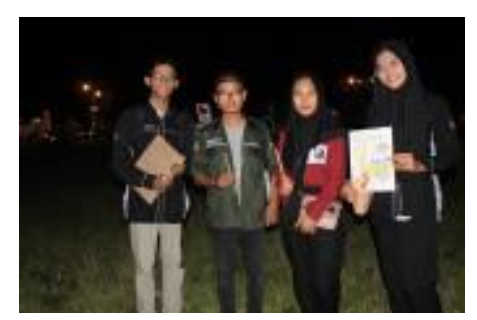

Gambar 4. Kegiatan sosialisasi pada pengunjung Alun-Alun Selatan Yogyakarta

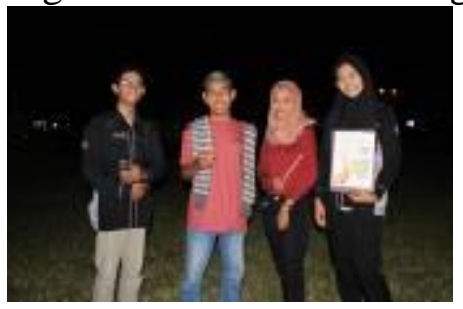

Gambar 5. Kegiatan sosialisasi pada pengunjung Alun-Alun Selatan Yogyakarta

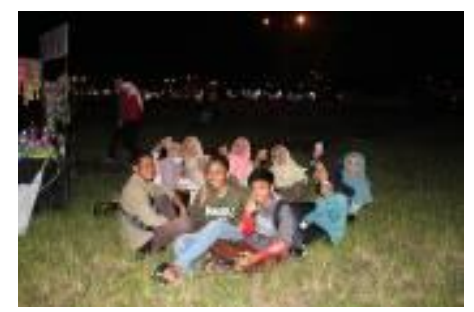

Gambar 6. Kegiatan sosialisasi pada pengunjung Alun-Alun Selatan Yogyakarta

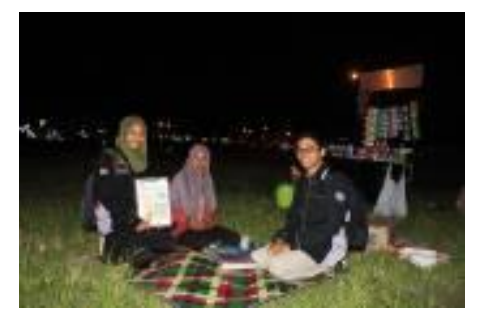

Gambar 7. Kegiatan sosialisasi pada Pemilik warung Di Alun-Alun Selatan Yogyakarta 


\section{Kesimpulan}

Kesimpulan dari hasil yang telah dibahas bahwa masyrakat sebenarnya memiliki kesadaran akan cinta lingkungan. Akan tetapi perlu diadakannya gerakan untuk mendorong rasa cinta lingkungan masyarakat tersebut terpenuhi dan terfasilitasi.

\section{Ucapan Terima Kasih}

Ucapan terima kasih diberikan kepada Kepala SD Muhammadiyah Blunyah dan pengunjung serta pemilik warung diwilayah wisata Alun-Alun Selatan Yogyakarta.

\section{Pustaka}

Annisa, s. (2019). Studi netnografi pada aksi beat plastic pollution oleh united nations environment di media sosial instagram. Jurnal aspikom, 3(6), 1109. Https://doi.org/10.24329/aspikom.v3i6. 411

Balai lingkungan hidup. (2013). Buku data status lingkungan hidup daerah kota yogyakarta tahun 2013 pemerintah kota yogyakarta.

Dewi, i. G. A. A. Y. (2018). 111 issn 25812378 copyright (02018. Jurnal administrasi publik, 111-125.

Handziko, r. C. (2017). Wisata edukasi kampus melalui pelatihan pengamatan burung untuk siswa sekolah menengah atas. Jurnal pengabdian masyarakat mipa dan pendidikan mipa, 1(2), 99104.

Https://doi.org/10.21831/jpmmp.v1i2.1 5566

Hodriana, et al. (2013). Studi netnografi pada aksi beat plastic pollution oleh united nations environment di media sosial instagram. Jurnal inovasi pendidikan, 6(2), 1109.

Karuniastuti, n. (2017). Bahaya plastik terhadap kesehatan dan lingkungan. Forum tenologi, 03(1), 6-14. Https://doi.org/https://dx.doi.org/10.112 8/cvi.00526-12

Martana, b., nashir, a. K., pradana, s., studi, p., mesin, t., pembangunan, u., ... veteran, n. (2018). Pengolahan sampah plastik menjadi produk lainnya sebagai upaya peningkatan ekonomi masyarakat. 2018, 23-25.

Nabila, i. D. (2017). Pemanfaatan limbah sendok plastik untuk diaplikasikan sebagai produk perhiasan. E-proceeding of art \& design, 4(3), 1009-1028.

Nasution, r. S. (2015). Berbagai cara penanggulangan limbah plastik. Journal of islamic science and technology, l(1), 97-104.

Nugroho, a. S., rahmad, r., \& suhartoyo, s. (2018). Pemanfaatan limbah plastik sebagai energy alternatif. Simetris: jurnal teknik mesin, elektro dan ilmu komputer, 9(1), 55-60. Https://doi.org/10.24176/simet.v9i1.177 2

Putra, h. P., \& yuriandala, y. (2010). Studi pemanfaatan sampah plastik menjadi produk dan jasa kreatif. Jurnal sains \&teknologi lingkungan, 2(1), 21-31. Https://doi.org/10.20885/jstl.vol2.iss1.a $\mathrm{rt3}$

Ridho, a. (2016). Dari sampah plastik dengan metode computer. 1(2), 24-27.

Sabatari, w. (2007). Pemanfaatan limbah sedotan aqua gelas. (september). 